\title{
Blood protozoans in elasmobranchs of the family Rajidae from Galicia (NW Spain)
}

\author{
W. Aragort $^{1}$, M. F. Alvarez ${ }^{2}$, J. L. Leiro ${ }^{2}$, M. L. Sanmartín ${ }^{1,2, *}$ \\ ${ }^{1}$ Avenida Principal Las Delicias, Unilab, Sanidad Animal, Instituto Nacional de Investigaciones Agrícolas (INIA). \\ Maracay, Estado Aragua, Venezuela \\ ${ }^{2}$ Instituto de Investigación y Análisis Alimentarios (IIAA), Universidad de Santiago de Compostela, \\ C/Constantino Candeira s/n, 15782, Santiago de Compostela, Spain
}

\begin{abstract}
Blood smears from 132 skates Raja spp. captured on the continental shelf off Galicia (NW Spain) were examined for blood parasites. The skate species were Raja brachyura $(\mathrm{n}=60), R$. microocellata $(\mathrm{n}=52$ ) and a total of 20 specimens belonging to $R$. undulata, $R$. montagui and another 2 unidentified Raja species, all captured between March 1999 and March 2000. Two blood parasite species were found, Trypanosoma giganteum and Haemogregarina delagei. Of the 132 skates, $16 \%$ were infected only by $T$. giganteum, $17 \%$ only by $H$. delagei, and $5 \%$ by both $T$. giganteum and $H$. delagei. Both parasites showed highest prevalence in $R$. brachyura $(22 \%$ T. giganteum only, $38 \%$ $H$. delagei only, $12 \%$ T. giganteum and $H$. delagei). Mean leucocyte percentages ( $=132$ fish) were lymphocytes $(43 \%)$, eosinophils $(35 \%)$, neutrophils $(20 \%)$ and monocytes $(2 \%)$; basophils were not found. As far as we are aware, this eosinophil percentage is the highest reported to date for elasmobranchs. We did not detect any statistically significant differences in leucocyte percentages between infected and uninfected fish, between male and female fish, among species or among weight groups
\end{abstract}

KEY WORDS: Haemogregarina delagei · Trypanosoma giganteum · Raja spp. · Blood parasites · Leucocyte counts · Galicia (NW Spain)

Resale or republication not permitted without written consent of the publisher

\section{INTRODUCTION}

Relatively little is known about the diseases of elasmobranchs or about possible haematological effects of blood parasites in these fishes. Examination of blood smears allows both detection of blood parasites and characterization of the different types of elasmobranch blood cells, namely erythrocytes, leucocytes and platelets (Kjeldsberg 1994). Leucocytes are conventionally classified on morphological grounds into 5 categories: neutrophils, lymphocytes, monocytes, eosinophils and basophils. Their abundances in blood vary widely, depending on species and physiological condition (Kjeldsberg 1994).

A recent study of a trypanosome-infected population of the red-spotted catshark Schroederichthys chilensis (Guichenot, 1848) (infection prevalence 87\%) found the highest eosinophil percentage reported to date in fishes (Valenzuela et al. 2003).

In the present study, we examined blood smears from a total of 132 specimens of various Raja species (family Rajidae) captured in the northeast Atlantic off Galicia (NW Spain), with the aim of detecting blood parasites and estimating their prevalences. We also performed leucocyte counts in smears from each fish specimen to assess whether infection by blood parasites affects the composition of the leucocyte population.

\section{MATERIALS AND METHODS}

A total of 132 elasmobranchs were caught between March 1999 and March 2000 on the continental shelf off the estuary of Muros and Noia: 60 Raja brachyura Lafont, 1873 (27 males, 23 females, 10 indeterminate); 52 Raja microocellata Montagu, 1818 (24 males, 26 females, 2 indeterminate), and a total of 20 specimens belonging to the species Raja montagui Fowler, 1910, Raja undulata Lacepede, 1802, and 2 unidentified Raja species. Since the total of these latter 4 species was only 20 specimens (of which 13 were males, 
5 females and 2 indeterminate), they were considered together as 'other species'. The map coordinates of the capture area were $42^{\circ} 35^{\prime}$ to $42^{\circ} 41^{\prime} \mathrm{N}, 09^{\circ} 02^{\prime}$ to $09^{\circ} 10^{\prime} \mathrm{W}$; mean capture depth was $11.64 \pm 4.11 \mathrm{~m}$. All specimens were captured with local traditional fishing apparatus called 'trasmallos' or 'miños' (Rivas Lago 1996).

Specimens were transferred to the laboratory in refrigerated containers, and analysed immediately: the heart was dissected out and used to obtain 3 blood smears ( 2 thin smears, and 1 thick smear). The thin smears were air-dried at ambient temperature, then fixed with methanol and stained with Giemsa, MayGrunwald-Giemsa or Wright's stain. The thick smear was viewed fresh. All smears were examined by light microscopy (40x), noting the presence or absence of blood parasites. The trypanosomes found were measured with a calibrated micrometer, following the procedure described by Lom \& Dyková (1992).

Prevalence was calculated according to Bush et al. (1997). Trypanosoma abundance, being very scarce, is given as the number of specimens per smear in infected hosts. Haemogregarina abundance is given as the mean parasite density and calculated by counting the number of erythrocytes per 100 microscope fields in each infected host, taking note of the number of infected erythrocytes in each host. The percentage (= density) of infected erythrocytes was then calculated for each host, from which the mean density was calculated.

Leucocyte counts were obtained by examining 100 leucocytes in a thin smear, and counting the number of lymphocytes, monocytes, eosinophils, neutrophils and basophils. The percentage of each cell type was thus determined for each individual ray. From these data, the mean and standard deviation for each fish species (Raja montagui, R. microocellata, 'other species') or sex were calculated.

The data thus obtained for each type of leucocyte did not show a normal distribution in most cases, so nonparametric tests were used for data analysis. Means were compared between male and female fish of each species by the Mann-Whitney $U$-test, and among fish species by the Kruskal-Wallis test followed by Dunn's test for one-to-one comparison of means. The KruskalWallis test was also used to compare means among fish infected with none, 1 or both blood parasite species. To investigate possible influences of host age on infection prevalences, we divided the rays into 4 different groups by weight: (1) up to $500 \mathrm{~g}$, (2) 501 to $1000 \mathrm{~g}$, (3) 1001 to $1500 \mathrm{~g}$, and (4)>1500 g, and determined the prevalence of each parasite species in each group; prevalences were compared between groups by Fisher's exact test. All statistical analyses were performed with the aid of GraphPad InStat version 3.05 (GraphPad Software).

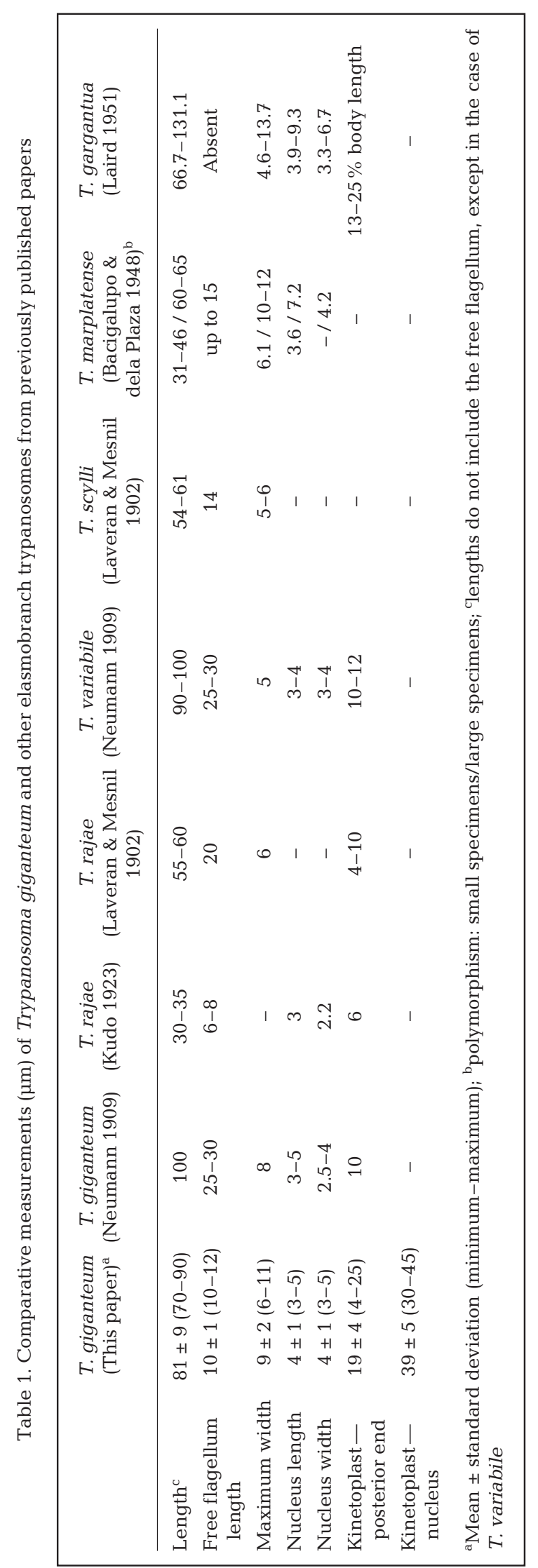




\section{RESULTS AND DISCUSSION}

Two blood parasites were found, Trypanosoma giganteum Laveran \& Mesnil, 1902 and Haemogregarina delagei Laveran \& Mesnil, 1901.

The morphology of Trypanosoma giganteum coincides approximately with that reported by Neumann (1909) (measurements in Table 1), though with some minor differences, notably an apparently shorter free flagellum (10 \pm $1 \mu \mathrm{m})$. This may be a preparation artefact, or may reflect the fact that the flagellum was in most cases coiled freely or around an erythrocyte (Fig. 1), making accurate measurement difficult. Also, the kinetoplast-posterior end distance was slightly longer than that given by Neumann (1909).

Haemogregarina delagei (Fig. 2) was observed in various stages. Firstly, inside erythrocytes, 2 types of development stages were observed. Gamonts were banana-shaped (Fig. 2A,D), with measurements $(11 \pm 1 \mu \mathrm{m} \times 2 \pm 1 \mu \mathrm{m})$ very similar to those described by Lom \& Dyková (1992) $(11.3 \times 3.7 \mu \mathrm{m})$. With Giemsa staining, they showed grey or light blue cytoplasm; the nucleus was stained dark, like that of host erythrocytes, and had a granular appearance. The second less frequent type was oval in shape, and smaller (length $6 \mu \mathrm{m}$ ) (Fig. 2E). No differences in size were observed between infected and uninfected erythrocytes, and infected erythrocytes contained only a single parasite. Secondly, in plasma, we observed banana-shaped merozoites similar in shape and size to the large gamonts seen in erythrocytes (Fig. 2B,C); and thirdly, in 1 host, groups of 8 to 12 merozoites were observed free in plasma - these were arranged like the rays of a fan and measured $18 \times$ $3 \mu \mathrm{m}$ (Fig. 2F). This might be the final phase of merogony freed from ruptured erythrocytes.

Prevalences of the 2 parasite species are summarized in Table 2. About $5 \%$ of fish examined were infected by both species. The host with the highest prevalences of both species was Raja brachyura, while Raja microocellata showed far lower values, in particular for Haemogregarina delagei. Infection by both parasite species together was likewise more common in $R$. brachyura. Trypanosoma giganteum was very scarce in the infected hosts, with only 0 to 2 specimens per thin blood smear examined. $H$. delagei was slightly
Table 3. Trypanosoma giganteum and Haemogregarina delagei from Raja spp. Prevalences (\%) in fish (all species) grouped by weight. $\mathrm{n}=$ number of skates in each weight group

\begin{tabular}{|lccc|}
\hline $\begin{array}{l}\text { Weight groups } \\
(\mathrm{g})\end{array}$ & $\mathrm{n}$ & $\begin{array}{c}\text { T. giganteum } \\
(\%)\end{array}$ & H. $\begin{array}{l}\text { delagei } \\
(\%)\end{array}$ \\
\hline$\leq 500$ & 7 & 0 & 0 \\
$501-1000$ & 49 & 16.7 & 12.5 \\
$1001-1500$ & 57 & 19.3 & 21.0 \\
$>1500$ & 19 & 10.5 & 36.6 \\
\hline
\end{tabular}

more abundant, and was present in $2 \%$ of the erythrocytes examined in both $R$. branchyura and $R$. microocellata and also in the 'other species' group.

As shown in Table 3, neither parasite was found in fish weighing less than $500 \mathrm{~g}$, although this might be due to the small number of skates in this group. In the remaining 3 weight groups, no clear trend 


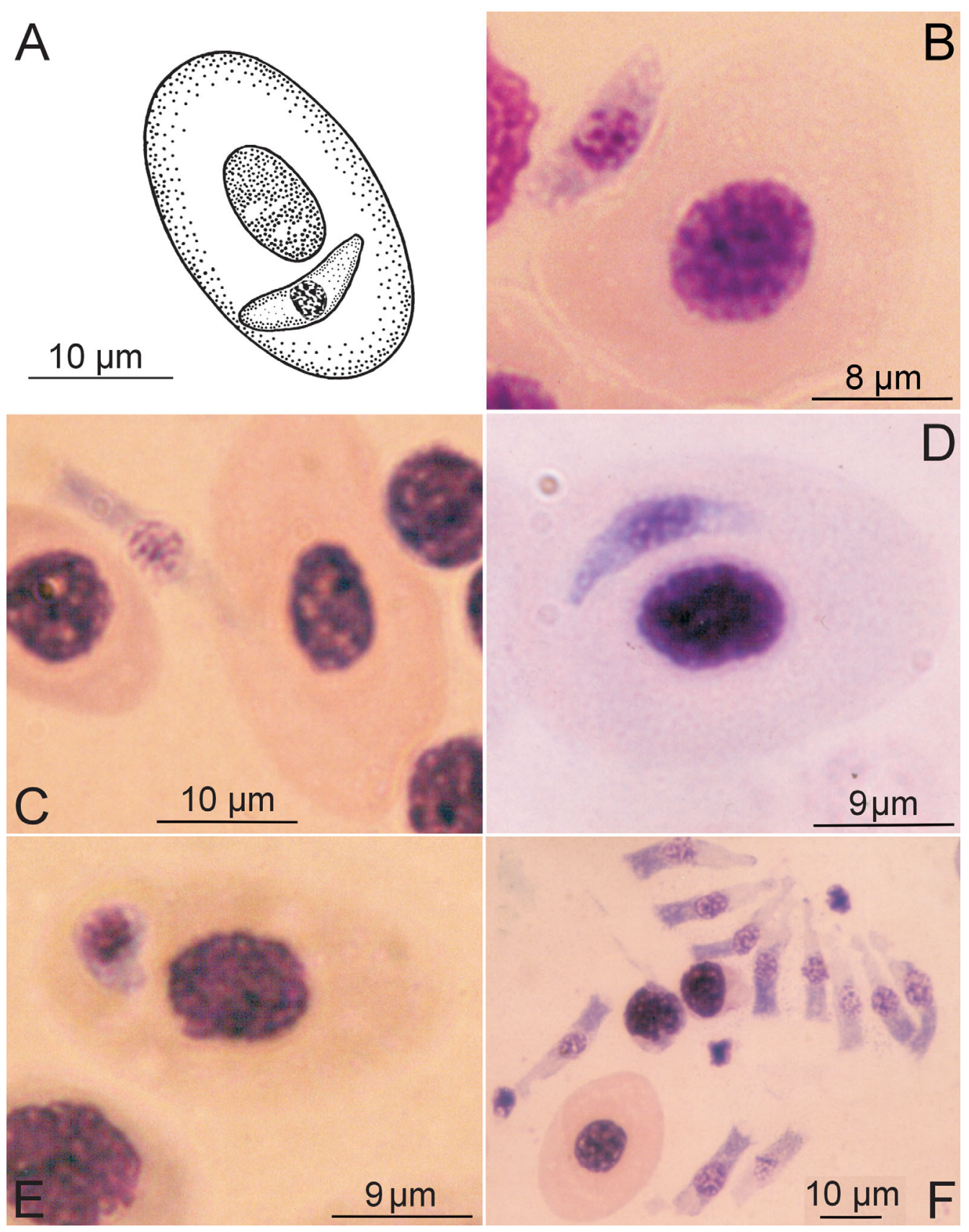

Fig. 2. Haemogregarina delagei. (A) Camera lucida drawing of gamont within erythrocyte. (B) Merozoite free in blood. (C) Merozoite penetrating erythrocyte. (D) Banana-shaped gamont within erythrocyte. (E) Small ovaloid specimen within erythrocyte. (F) Final phase of merogony free in plasma

was observed for Trypanosoma giganteum, nor were between-group differences statistically significant. Prevalence of Haemogregarina delagei increased with weight, but the between-group differences were not statistically significant.

Table 4 shows prevalences in male and female fish. In Raja microocellata, both parasite species showed higher prevalence in males than in females, while in Raja brachyura both parasite species showed higher prevalence in females; however, none of these between-sex differences were statistically significant.

Numerous species of the genus Trypanosoma have been described from elasmobranchs. Trypanosoma giganteum was described by Neumann (1909) in Raja 
oxyrhynchus from European waters. We are not aware of any other reports of this species. Other trypanosome species that have been reported from Raja spp. (see Table 1) include T. rajae Neumann, 1909 in $R$. punctata, $R$. clavata and $R$. radiata (Lom \& Dyková 1992); $T$. gargantua Laird, 1951 in $R$. nasuta from New Zealand (Laird 1951); and T. variabile Neumann, 1909

Table 4. Trypanosoma giganteum and Haemogregarina delagei from Raja spp. Prevalences of the 2 blood parasites in male and female fish

\begin{tabular}{|lcccc|}
\hline & \multicolumn{2}{c|}{ T. giganteum (\%) } & \multicolumn{2}{c|}{ H. delagei (\%) } \\
& Males & Females & Males & Females \\
\hline R. microocellata & 20.8 & 8.0 & 4.2 & 0 \\
R. brachyura & 14.8 & 30.4 & 40.7 & 47.8 \\
Other species & 7.7 & 0 & 0 & 0 \\
\hline
\end{tabular}

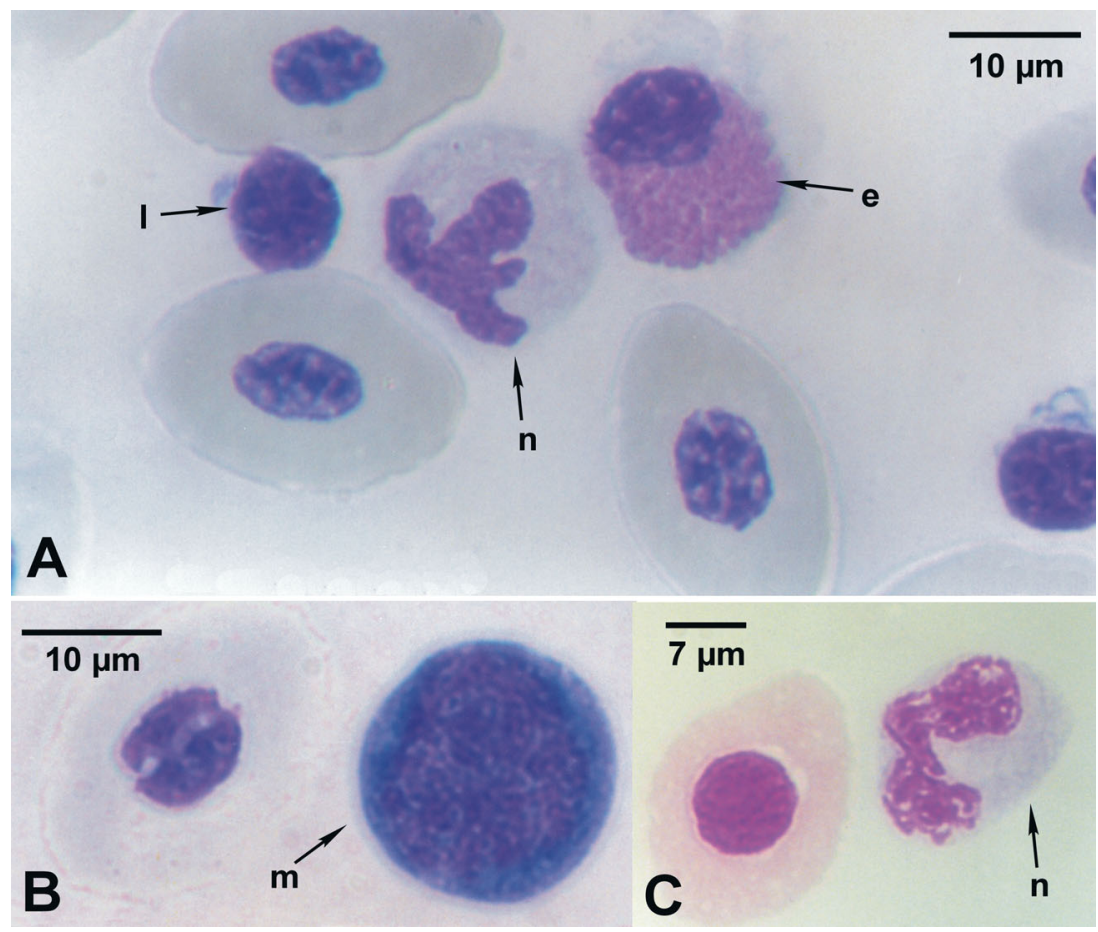

Fig. 3. Leucocyte types in Raja spp. (A) Lymphocyte (l), neutrophil (n) and eosinophil (e). (B) Monocyte (m). (C) Neutrophil (n)

Table 5. Leucocyte count percentages in the different Raja species. Mean percentages \pm standard deviation (minimum-maximum)

\begin{tabular}{|lcccc|}
\hline & $\begin{array}{c}\text { Lymphocytes } \\
(\%)\end{array}$ & $\begin{array}{c}\text { Monocytes } \\
(\%)\end{array}$ & $\begin{array}{c}\text { Eosinophils } \\
(\%)\end{array}$ & $\begin{array}{c}\text { Neutrophils } \\
(\%)\end{array}$ \\
\hline R. microocellata & $43 \pm 14(12-80)$ & $3 \pm 6(0-24)$ & $34 \pm 12(12-68)$ & $20 \pm 11(0-44)$ \\
$R$. brachyura & $44 \pm 15(12-72)$ & $2 \pm 5(0-32)$ & $36 \pm 15(8-84)$ & $18 \pm 10(0-44)$ \\
Other species & $43 \pm 14(12-80)$ & $2 \pm 5(0-32)$ & $35 \pm 14(8-84)$ & $20 \pm 10(0-44)$ \\
\hline
\end{tabular}

(now considered a synonym of $T$. rajae) in $R$. punctata. The species $T$. scylli and T. rajae have been found in the anterior intestine of elasmobranchs (Lom \& Dyková 1992). T. humboldti Morillas, Nascimento \& Khan, 1987, has been reported from the red-spotted catshark Schroederichthys chilensis (Guichenot, 1848) by Valenzuela et al. (2003).

The type species of the genus Haemogregarina is $H$. stepanowi Danilewky, 1885, a parasite of Emys orbicularis Linnaeus, 1758. Numerous species have been described from reptiles, amphibians and fishes, over a very wide geographic range (Daves \& Johnston 2000). These parasites infect both red and white blood cells (Cheung 1992).

Haemogregarina delagei is one of a group of species lacking a polar cap (Lom \& Dyková 1992); this group also includes $H$. platessae Lebailly, 1904 (gamonts 7.7 $\times 1.4 \mu \mathrm{m}), H$. nothotheniae Barber, Mills, Westermann \& Storoz, 1987 (gamonts 15 to 22 $\mu \mathrm{m})$ and $H$. myoxocephali Fantham, Porter \& Richardson, 1942 (gamonts $7.8 \times 2.4 \mu \mathrm{m})$. H. delagei is common in Raja erinacea Mitchill, 1825 (Siddall \& Desser 2001) and in Squalus acanthias Linnaeus, 1758 (Lom \& Dyková 1992). This is the first report of $H$. delagei in $R$. microocellata and $R$. brachyura. Our morphometric data (gamonts $11 \pm 1 \times 2 \pm 1 \mu \mathrm{m}$ ) coincide with those reported previously by Lom \& Dyková (1992), i.e. $11.3 \times 3.7 \mu \mathrm{m}$.

In diverse marine fishes in the northwest Atlantic, Khan et al. (1980) found Haemogregarina spp. to be present with a high prevalence (36\%). This value is similar to that which we obtained in Raja brachyura (38\%), while the values for the other Raja species were much lower (Table 2). Siddall \& Desser (2001) found $H$. delagei in $R$. erinacea with prevalences of between 77 and $91 \%$.

Fig. 3 shows the different types of leucocytes found in the present study. No basophils were found. We did not detect significant differences in leucocyte counts between fish infected with Trypanosoma giganteum, fish infected with Haemogregarina delagei, fish infected with both species, or fish not infected with either. Likewise, we did not detect significant differ- 
ences between male and female fish of each species, or among fish species. Similarly, Siddall \& Desser (2001) did not detect any relationship between leucocyte counts and host sex, or presence/absence of $H$. delagei, while Valenzuela et al. (2003) likewise did not detect any relationship between leucocyte counts and host sex, or presence/absence of $T$. humboldti.

Total leucocyte counts in the present study were similar to those reported previously for elasmobranchs (Stoskopf 1992), but leucocyte percentages showed some differences: notably, eosinophil counts (Table 5) were markedly higher than in previous studies (Stoskopf 1992, Valenzuela et al. 2003). The eosinophil percentage obtained by Valenzuela et al. (2003) in Schroederichthys chilensis infected (87\% prevalence) with Trypanosoma humboldti was lower than in the present study (15 to $25 \%$ vs. about $35 \%$ ) but nevertheless high, and these authors suggested that this eosinophilia might be physiologically normal for $S$. chilensis, and not attributable to the presence of the trypanosome. Our results with Raja species and $T$. giganteum support this hypothesis.

Acknowledgements. This work was financially supported by grant PGIDIT02RMA23701PR from the Xunta de Galicia, Spain.

\section{LITERATURE CITED}

Bacigalupo J, de la Plaza, N (1948) Presencia de tripanosomas en las rayas de Mar del Plata. Trypanosoma marplatensis, n. sp.. Rev Soc Argentina Biol 24:269-274

Bush AO, Lafferty KD, Lotz JM, Shostak AW (1997) Parasitology meets ecology on its own terms: Margolis et al. revis-

Editorial responsibility: Wolfgang Körting,

Hannover, Germany ited. J Parasitol 83:575-583.

Cheung P (1992) Parasitic diseases of elasmobranchs. In: Stoskopf MK (ed) Fish Medicine. W. B. Saunders Company, Philadelphia, PA, p 782-807

Daves AJ, Johnston MRL (2000) The biology of some intraerythrocytic parasites of fishes, amphibia and reptiles. Adv Parasitol 45:1-107

Khan RA, Murphy J, Taylor D (1980) Prevalence of a trypanosome in Atlantic cod (Gadus morhua) especially in relation to stocks in the Newfoundland area. Can J Fish Aquat Sci 37:167-1475.

Kjeldsberg CR (1994) Principios del exámen hematológico. In: Lee GR, Bithell TC, Foerster J, Athens JW, Lukens JN (eds) Wintrobe Hematología Clínica. Editorial InterMédica, Buenos Aires, p 6-31

Kudo R (1923) Skate trypanosome from Woods Hole. J Parasitol 9:179-180

Laird M (1951) Studies on the trypanosomes of New Zealand fish. Proc Zool Soc Lond 121:285-309

Laveran A, Mesnil F (1902) Des trypanosomes des poissons. Arch Protistenkd 1:475-598

Lom J, Dyková I (1992) Protozoan parasites of fishes. Development in Aquaculture and Fisheries Science, 26. Elsevier, Amsterdam

Neumann RO (1909) Studien über protozoische Parasiten im Blut von Meeresfischen. Z Hyg Infektionskr 64:1-112

Rivas Lago RA (1996) Manual Marítimo-Pesqueiro de Galicia. Edicions Xerais de Galicia, Vigo

Siddall ME, Desser SS (2001) Developmental stages of Haemogregarina delagei in the leech Oxytonostoma typica. Can J Zool 79:1897-1900.

Stoskopf MK (1992) Clinical pathology of sharks, skates and rays. In: Stoskopf MK (ed) Fish medicine. W. B. Saunders Company, Philadelphia, PA, p 754-757

Valenzuela A, Oyarzún C, Silva V (2003) Células sanguíneas de Schroederichthys chilensis (Guichenot 1848) (Elasmobranchii, Scyliorhinidae): La serie blanca. Gayana 67: $130-137$

Submitted: June 7, 2004; Accepted: November 30, 2004 Proofs received from author(s): June 10, 2005 